\title{
The Information Literacy Self-efficacy of Disadvantaged Teachers in South Africa
}

\author{
Sandy E. Zinn \\ University of the Western Cape, Department of Library \& Information \\ Science, Cape Town, South Africa
}

\begin{abstract}
The aim of this study was to gauge teachers' information literacy self-efficacy thereby eliciting clues to possible gaps in teachers' knowledge and skills which could be addressed during an information literacy education course. Twenty-nine teachers completed a pre-and post-course information literacy questionnaire. The teachers were part of a school librarianship programme offered at the University of the Western Cape. The results of the study indicate that the intervention of the course had a positive effect on teachers' information literacy.
\end{abstract}

Keywords: Information literacy, teachers, self-efficacy, South Africa

\section{Introduction}

The South African school curriculum implies that schools have access to a range of information resources. One of the cross curricula outcomes states that learners will be able to collect, organise, analyse and critically evaluate information. The irony is that $80 \%$ of schools in the Western Cape Province, where the study was conducted, are without functioning libraries or librarians. The onus then surely rests on teachers to mediate information literacy (IL) in the classroom.

The researcher undertook to investigate teachers' IL using 29 volunteering teachers participating in an information literacy education (ILE) course, one course in a school librarianship programme. The participants came from a mix of urban and rural schools and their average age was 46 years. One common element was that the schools they represented are some of the poorest in the country and without school libraries.

The research questions asked: 1)What are teachers' beliefs about their information literacy abilities? 2) At what level are teachers' knowledge and skills? 3) How familiar are teachers with research protocols/practice? 4) To what extent can an intervention change teachers' information literacy outlook? 


\section{Self-efficacy}

Self-efficacy can be defined as an individual's own beliefs about what he or she is capable of doing. A person's ability to actually achieve a goal is related to whether or not that person believes that the goal can be successfully achieved [1]. The concept of self-efficacy is central to Bandura's social cognitive theory, which posits that personality is an interaction between three components: the environment, behaviour, and one's psychological processes. A person develops a sense of selfefficacy through actual experiences, observation of others' experiences and through listening to other people's commentary about the person's capabilities [2]. Selfefficacy is about beliefs and not actual skill levels. According to Bandura's theory, people with high self-efficacy believe they can succeed and are more likely to tackle difficult jobs thinking they can accomplish them. Alternatively, people with low selfefficacy believe that tasks are more difficult than they really are and tend to avoid them [1]. Self-efficacy beliefs determine the lengths to which people will persevere and how resilient they will be when faced with difficulties and how much effort they will expend on an activity [3].

Self-efficacy has been used in a variety of fields since Bandura developed the concept in 1977. For example, Schwarzer \& Jerusalem's [4] health psychology generalised scale; Waldman's [5] study on freshmen's use of the library's electronic resources; the Pajares \& Schunk [6] study of self-efficacy in academic achievement; and Kurbanoglu's [7] link between self-efficacy and IL.

The researcher had previously taught ILE to a group of teachers in a different South African province. The experience presented her with troubling questions about IL and teacher education, one of which was related to self-efficacy. The IL selfefficacy 28-item scale presented a way of identifying the perceived competency and confidence in IL. The scale is not intended to measure the actual IL capabilities of participants. The pre-test questionnaire assisted the researcher in determining a baseline of confidence in IL amongst the participants. High confidence levels are associated with positive outcomes. In academic studies it has been found that students with high self-efficacy beliefs achieve successful outcomes by increasing motivation, effort, and focus on the task at hand while decreasing anxiety and dispelling negative thinking [2]. These studies show that 'self-efficacy beliefs influence self-regulatory processes such as goal setting, self-monitoring; selfevaluation and strategy use'. The higher the self-efficacy of students the more likely they will aim their goals higher and their self-monitoring strategies will be more effective [8], [5].

Self-efficacy varies from one subject to another. For example, a person may have high self-efficacy beliefs in using printed information such as books and magazines but may have low self-efficacy beliefs in using online information. Self-efficacy beliefs are also not static and may change over time with different experiences and exposure. It was hoped that with different and positive experiences participants' selfefficacy in relation to IL would rise. Seventy six percent (76\%) of the study participants teach in primary schools. These teachers trained before the new 
curriculum came into being in 1997. The training did not include IL nor did it provide a method for teaching children how to conduct research projects, a vehicle for developing IL. Participants were not expected to conduct research themselves so that conducting and writing up research was very new to them.

\section{Links Between Self-efficacy and Information Literacy}

Pajares and Schunk [6] and Waldman [5] show through their studies that 'selfefficacy beliefs influence self-regulatory processes such as goal setting, selfmonitoring; self-evaluation and strategy use". An information literate person embodies the attitude that learning is life long. To be a lifelong learner you need to be able to self-regulate - actions of independent learning and self-reflection come into play here. Such a person understands that the only constant in today's knowledge society is change. This person adopts a flexible approach to learning, aware that the information landscape is constantly changing. An IL person has traits that recognise that IL skills and abilities need to be honed and that excellence in knowledge production takes time and perseverance. An IL person in today's information society has a high self-efficacy because such a person can use an inquirybased framework to read for understanding, ultimately creating new knowledge and understanding.

The developers of the IL self-efficacy questionnaire utilized well known IL standards and outcome statements emanating from the AASL [9], ACRL [10], SCONUL [11], and Doyle's [12] traits of an information literate person, amongst others [3]. The questionnaire addresses IL according to the following seven broad criteria: 1) Defining the problem (Section A); 2) Developing a search strategy (Section B); 3) Finding \& gathering information (Section C); 4) Evaluating \& using information (Section D); 5) Synthesizing information (Section E); 6) Presenting findings (Section F); and 7) Reflecting on the process and product (Section F). The Likert scale range is as follows: $7=$ almost always true, $6=$ usually true, $5=$ often true, $4=$ occasionally true, $3=$ sometimes but infrequently true, $2=$ usually not true and $1=$ almost never true.

\section{Results of the Study}

The questionnaire was developed and refined by Kurbanoglu, Akkoyunlu \& Umay over a period of a few years (2003-2006). The 28-item IL self-efficacy questionnaire with a seven point Likert scale has a high Cronbach's alpha of 0.91. The correlation coefficient of the test-retest indicates reliability for the 28 -item scale as high.

The null hypothesis of the current study is that there is no difference between the IL scores on the 28-item scale before and after the ILE course.

Table 1 on the next page compares the mean scores per item (28 items) for the pre- and post-course IL self-efficacy for the 29 participants. 
Both the pre-course questionnaire scores and the post-course questionnaire scores were taken from the same source of 29 participants with each data value in one sample having a corresponding data value in the other sample. By applying the Jaque-Bera test to the sample paired differences, the conclusion reached at $5 \%$ significance level $(\mathrm{p}=0.05)$ is that the population paired differences can assumed to be normally distributed. Thus, based on the mean summaries in table (1) below, the mean pre-course scores and the post-course scores are tested for significant differences or not.

With $\mathrm{d}=24.7$ (the mean of the sample of paired differences) and $\mathrm{s}=40.1$ (standard deviation of the sample of paired differences), then the t-test statistic $=-3.3$ and the critical value is $\mathrm{t}=-\mathbf{2} .8$ with 28 degrees of freedom, $\mathrm{p}=0.005$. Therefore, because the critical value $(-2.8)$ is larger than the test statistic $(-3.3)$, the conclusion reached is that there is enough statistical evidence to suggest that the pre-course IL self-efficacy scores and the post-course self-efficacy scores are statistically different.

Table 1 Comparison of mean scores for the pre-and post-course IL self-efficacy $(\mathrm{n}=29)$

\begin{tabular}{llllll}
\hline \multirow{2}{*}{ Items } & $\begin{array}{l}\text { Pre- } \\
\text { test }\end{array}$ & \multicolumn{3}{c}{$\begin{array}{l}\text { Post- } \\
\text { test }\end{array}$} \\
\cline { 3 - 7 } & & $\boldsymbol{\mu}$ & $\boldsymbol{s}$ & $\boldsymbol{\mu}$ & $\boldsymbol{s}$ \\
\hline A1 & Define the information need & 4.5 & 1.4 & 5.3 & 1.1 \\
\hline B2 & $\begin{array}{l}\text { Identify a variety of potential sources } \\
\text { of information }\end{array}$ & 4.7 & 1.1 & 5.3 & 1.1 \\
\hline B3 & $\begin{array}{l}\text { Limit search strategies by subject, } \\
\text { language and date }\end{array}$ & 4.5 & 1.0 & 4.9 & 0.9 \\
\hline B4 & $\begin{array}{l}\text { Initiate search strategies by using } \\
\text { keywords and Boolean logic }\end{array}$ & 4.3 & 1.2 & 5.1 & 1.1 \\
\hline C5 & $\begin{array}{l}\text { Decide where and how to find the } \\
\text { information needed }\end{array}$ & 4.7 & 1.2 & 5.3 & 0.7 \\
\hline C6 & Use different kinds of print sources & 5.0 & 1.6 & 5.5 & 1.1 \\
\hline C7 & Use electronic information sources & 4.4 & 1.5 & 5.5 & 1.2 \\
\hline C8 & $\begin{array}{l}\text { Locate information sources in the } \\
\text { library }\end{array}$ & 4.8 & 1.4 & 5.4 & 1.1 \\
\hline C9 & Use library catalogue & 4.4 & 1.8 & 4.8 & 1.3 \\
\hline C1 & $\begin{array}{l}\text { Locate resources in the library using } \\
\text { the library catalogue }\end{array}$ & 4.3 & 1.2 & 4.6 & 1.4 \\
\hline C11 & Use internet search tools & 4.3 & 1.8 & 5.3 & 1.0 \\
\hline C1 & Use different kinds (types) of libraries & 4.5 & 1.6 & 5.2 & 1.0 \\
2 & & & & & \\
\hline D1 & Use many resources at the same time & 4.4 & 1.5 & 5.5 & 1.3 \\
\hline & & & & &
\end{tabular}




\begin{tabular}{|c|c|c|c|c|c|}
\hline 3 & to undertake research & & & & \\
\hline $\begin{array}{l}\mathrm{D} 1 \\
4\end{array}$ & $\begin{array}{l}\text { Determine the authoritativeness, } \\
\text { currency and reliability of the } \\
\text { information sources }\end{array}$ & 3.8 & 1.4 & 4.8 & 1.2 \\
\hline $\begin{array}{l}\text { D1 } \\
5\end{array}$ & $\begin{array}{l}\text { Select information most appropriate } \\
\text { to the information need }\end{array}$ & 4.5 & 1.3 & 5.4 & 0.9 \\
\hline $\begin{array}{l}\mathrm{D} 1 \\
6\end{array}$ & $\begin{array}{l}\text { Identify points of agreement and } \\
\text { disagreement among sources }\end{array}$ & 4.0 & 1.4 & 5.0 & 0.3 \\
\hline $\begin{array}{l}\text { D1 } \\
7\end{array}$ & Evaluate World Wide sources & 3.7 & 1.4 & 4.9 & 1.1 \\
\hline $\begin{array}{l}\text { E1 } \\
8\end{array}$ & $\begin{array}{l}\text { Synthesize newly gathered } \\
\text { information with previous } \\
\text { information }\end{array}$ & 4.3 & 1.3 & 5.1 & 1.0 \\
\hline $\begin{array}{l}\text { E1 } \\
9\end{array}$ & $\begin{array}{l}\text { Interpret the visual information } \\
\text { (graphs, tables, diagrams) }\end{array}$ & 4.5 & 1.5 & 5.2 & 1.2 \\
\hline $\begin{array}{l}\text { F2 } \\
\text { o }\end{array}$ & Write a research paper & 3.5 & 1.4 & 4.8 & 1.3 \\
\hline$\overline{\text { F21 }}$ & $\begin{array}{l}\text { Determine the content and form the } \\
\text { parts (introduction, conclusion) of a } \\
\text { presentation (written, oral) }\end{array}$ & 4.3 & 1.3 & 5.2 & 0.9 \\
\hline $\begin{array}{l}\mathrm{F} 2 \\
2\end{array}$ & Prepare a bibliography & 4.2 & 1.5 & 5.4 & 1.3 \\
\hline $\begin{array}{l}\text { F2 } \\
3\end{array}$ & $\begin{array}{l}\text { Create bibliographic records and } \\
\text { organize the bibliography }\end{array}$ & 4.0 & 1.4 & 5.2 & 1.2 \\
\hline $\begin{array}{l}\text { F2 } \\
4\end{array}$ & $\begin{array}{l}\text { Create bibliographic records for } \\
\text { different kinds of materials (i.e. } \\
\text { books, articles, pages) }\end{array}$ & 3.7 & 1.4 & 4.8 & 1.2 \\
\hline $\begin{array}{l}\text { F2 } \\
5\end{array}$ & $\begin{array}{l}\text { Make citations and use quotations } \\
\text { within the text }\end{array}$ & 3.6 & 1.4 & 4.9 & 1.1 \\
\hline $\begin{array}{l}\text { F2 } \\
6\end{array}$ & $\begin{array}{l}\text { Choose a format (i.e. written, oral, } \\
\text { visual) appropriate to communicate } \\
\text { with the audience }\end{array}$ & 4.0 & 1.5 & 5.4 & 1.2 \\
\hline $\begin{array}{l}\text { G2 } \\
7\end{array}$ & $\begin{array}{l}\text { Learn from the information problem } \\
\text { solving experience and improve } \\
\text { information literacy skills }\end{array}$ & 4.1 & 1.3 & $5 \cdot 5$ & 1.0 \\
\hline $\begin{array}{l}\mathrm{G} 2 \\
8\end{array}$ & $\begin{array}{l}\text { Criticize the quality of the } \\
\text { information seeking process and its } \\
\text { products }\end{array}$ & 4.0 & 1.4 & $5 \cdot 3$ & 1.1 \\
\hline
\end{tabular}




\section{Interpretation of the Results}

The pre-course and post-course questionnaire results are interpreted below:

\subsection{Interpreting the Pre-course Questionnaire Results}

The pre-course mean total of 117.6 (SD 31.7) or 4.2 in terms of the Likert scale indicates that the participants' self-efficacy was above average to begin with. The IL attribute about which participants felt most confident was using different kinds of print sources (score of $5=$ often true). This result makes sense as the teachers (participants) have had the most exposure to printed sources both in their preservice and in-service training. The lowest IL attribute went to writing a research paper (F20) which scored on average 3.5 (sometimes but rarely true). Seventy six percent $(76 \%)$ of the participants were primary school teachers who attended teacher training colleges where writing a research paper did not form part of the training. The category in which participants had the least self-efficacy was $\mathrm{F}$ - presenting or communicating information - with seven items and a mean score of 27.3 or 3.9 on the Likert scale. If teachers were themselves not confident and competent to do research and present their findings with the attendant bibliographic conventions, they could not be expected to be able to teach these tasks to their learners.

Category D, which involves engaging with different sources of information and assessing their worth, had two items scored below a 4: D14 - Determine the authoritativeness, currency and reliability of the information sources (score of 3.8; and D17 - Evaluate World Wide sources (score of 3.7). Teachers seem unfamiliar with the act of evaluating a source to determine its worth, particularly when it comes to online information. As mentioned before, teachers are more comfortable in the printed environment, but then again they seem to have taken printed material at face value not concerning themselves with bias or accuracy of printed sources.

\subsection{Interpreting the Post-course Questionnaire Results}

Statistically, there was a fairly significant leap in self-efficacy from the beginning of the course (total mean score of 117.6, SD of 31.7) to after the course (total mean score of 143.9, SD of 21.9). The category in which participants improved their self-efficacy the most was $F$ which advanced by 8 points on average (from 27.3 to 35.3 ). In the pre-course questionnaire, category F scores were on the whole the lowest. The course intervention seems to have boosted participants' confidence in carrying out research and communicating findings using academic conventions. The participants' perceived self-efficacy went from a low "sometimes but rarely true" to a relatively positive "often true" in terms of the Likert scale.

Category C, locating and assessing resources, improved from 35.7 to 40.9, a difference of 5.2 points and the second largest increase in self-efficacy. Ninety three percent (93\%) of the schools in which these participants teach do not have libraries. Using catalogues to locate resources would require lots of practice which the 
participants seemed to lack at the beginning. For $83 \%$ of participants the public library is within a $5 \mathrm{~km}$ radius of the school, but few indicated that they were active members of the public library. The teachers had already completed the School Librarianship course

information sources and reference services but still lacked confidence. During other school librarianship courses participants were introduced to different types of libraries such as university and education libraries and they were taken to exemplary school libraries. As part of the ILE course, participants' attitudes towards public libraries were challenged. As the majority had no school libraries, it was ludicrous to ignore a library in the community. Participants were exposed to the extensive collection of the education library, EDULIS. Teachers had to provide evidence that they had exposed learners to a wide variety of information sources. They had to show how learners had used different sources and provide a list of references in the correct bibliographic format.

Within category $\mathrm{C}$, items $\mathrm{C}_{7}$ and $\mathrm{C} 11$, both related to searching and using online tools, leapt from an average of $4.4-5.5$ points and $4.3-5.3$ points respectively. Successive exposure to online catalogues, electronic journals and web-based information increased the self-efficacy of the participants. For the ILE course in particular, teachers had to locate a minimum of five sites for each school subject to recommend to their colleagues. They were also taught to evaluate sites and expected to use resources in their research project with their learners. Within a short space of six months (a university semester) the teachers' self-efficacy grew remarkably.

Three category D items, D13, D14, and D17, improved on average by one point: D13 went from 4.4 to 5.5 ; D14 went from 3.8 to 4.8 ; and D17 went from 3.7 to 4.9 . In preparing teachers to mediate IL in their classrooms, teachers themselves needed to be comfortable using several sources simultaneously (D13). Teachers were taught how to ascertain the reliability and authoritativeness of information sources (D14) and to approach - based information more critically (D17) - with less trust and more skepticism.

There are only two items in the $\mathrm{G}$ category both of which are related to reflecting on the IL process and skills and reflecting on the product. Both items had improved scores rising from 4.1 to 5.5 and 4.0 to 5.3 respectively. For the course assessment, teachers had to implement a research project in their respective classrooms. The experience will have taught them invaluable lessons which would feed into an improved subsequent research project. One of the best ways of learning is through application in a real situation and/ or teaching others. When one teaches others, you first have to understand the topic or subject oneself, which requires comprehension, interpretation, synthesis and reflection. It is through reflection that metacognition occurs. Teachers have gained confidence through the course by not only learning about the information seeking process but by having to implement or apply it in the classroom. 


\section{Conclusions and Discussion}

The general self-efficacy scores of the participants rose from 117.6 to 143.9 or Likert scale 4.2 "occasionally true" to 5.1 "often true". If this study's results are compared, for example, with those of the Kurbanoglu [7] study on self-efficacy and IL at the Turkish Hacettepe University, these results relatively improved more from the preto the post-questionnaire. This study's scores went up by .9 whereas the Turkish study saw only slight improvements in comparing students' IL self-efficacy from first to third year: between first and second year there was an improvement of .6 points and from second to third year, an improvement of .26 points. Again, these are not actual skills being rated but beliefs or perceptions about being able to accomplish them.

The most important finding is that the ILE course appears to have improved the self-efficacy of the majority of participants in the study. Teachers' confidence in Web search skills and research practice appear to have improved after the course intervention. Measuring teachers' actual information literacy goes beyond a study based solely on self-efficacy.

\section{References}

1. Bandura, A.: Social Foundations of Thought and Action: A Social Cognitive Theory. Prentice-Hall, Englewood Cliffs, NJ (1986)

2. Bandura, A.: Self-efficacy: The Exercise of Control. Freeman, New York (1997)

3. Kurbanoglu, S., Akkoyunlu, B., Umay, A.: Developing the Information Literacy Self-efficacy Scale. Journal of Documentation 62, 635-646 (2006)

4. Schwarzer, R., Jerusalem, M.: Generalized Self-efficacy Scale. In: Weinman, J., Wright, S., Johnston, M. (eds) Measures in Health Psychology: A User's Portfolio. Causal and Control Beliefs, pp. 195-213. NFER-NELSON, Windsor (1995)

5. Waldman, M.: Freshmen's Use of Library Electronic Resources and Self-efficacy. Information Research 8, http://informationr.net/ir/8-2/paper15o.html (2003)

6. Pajares, F., Schunk, D.H.: Self-beliefs and School success: Self-efficacy, Selfconcept and School Achievement, http://des.emory.edu/mfp/PajaresSchunk2001.html (2001)

7. Kurbanoglu, S.: Self-efficacy: A Concept Closely Linked to Information Literacy and Lifelong Learning. Journal of Documentation 59, 635-646 (2003)

8. Pajares, F., Schunk, D.H.: Self-beliefs and School success: Self-efficacy, Selfconcept and School Achievement, 
http://des.emory.edu/mfp/PajaresSchunk2001.html (2001)

9. American Association of School Librarians (AASL): Standards for Student Learning. ALA, Chicago, IL (1998)

10. Association of College and Research Libraries (ACRL): Information Literacy Competency Standards for Higher Education. ALA, Chicago, IL (2002)

11. SCONUL: Seven Pillars of Information Literacy, http://www.sconul.ac.uk/groups/information_literacy/papers/seven_pillars.html (1999)

12. Doyle, C.S.: Information Literacy in an Information Society: A concept for the Information Age. Syracuse University, Syracuse, NY (1994) 